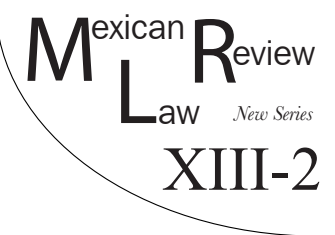

\title{
PERMANENT ECONOMIC EMERGENGY IN ARGENTINA AND ITS CONSTITUTIONAL IMPLICATIONS
}

\author{
Juan Santiago YLARRI*
}

\begin{abstract}
There is broad consensus among legal scholars about the existence of a permanent economic emergency in Argentina. This article examines the origin of the doctrine of economic emergency and its evolution in the Argentine Supreme Court of Fustice decisions. Various regulatory devices implemented to face the economic crises are analyzed, and it is emphasized that the declaration of a state of emergency has not been made only by means of Congress formal legislation, but through the legislative powers of the President. The requirements for the validity of regulations of emergency are set forth in this article, including the actual existence of a state of emergency, a public interest, that the measure be reasonable, and the provisional nature of the emergency. Considering that courts have not exerted proper judicial review over the regulations of emergency, guidelines to implement adequate judicial review over the subject at issue are presented. It is stated that the declaration of economic emergency and the factual circumstances underlying such declaration is a question subject to judicial review. In exercising the judicial review about this issue, two dimensions may be considered. First, timing, and, second, the correlation that must exist between a regulation - law, legislative delegation, or a decree of necessity and urgency - and the emergency situation it is intended to fight against. Finally, specific features of judicial review depending on the type of regulation that has declared the emergency are studied.
\end{abstract}

KEYWORDS: Economic emergency, declaration of economic emergency, legislative powers of the president, political question doctrine, judicial review.

RESUMEN: La doctrina coincide en la existencia de una emergencia económica permanente en la Argentina. En este artículo, se estudia el nacimiento de la

* Ph.D. in Law (Universidad de Buenos Aires). Master's in Constitutional Law (Centro de Estudios Políticos y Constitucionales, Spain). Researcher at Institute for Legal and Social Research "Ambrosio L. Gioja" (Universidad de Buenos Aires). Author of the book La emergencia económica. El control de constitucionalidad de la situación de emergencia económica y su declaración normativa (2019), and the book Los decretos-leyes y el control de la "extraordinaria y urgente necesidad"(2019). Email: juan@ylarri.com.ar. The author wishes to thank Mariano Vitetta and Nazareth Imperiale. Special thanks are also due to the editors of the Mexican Law Review for acute comments and for their editing suggestions. 
Esta revista forma parte del acervo de la Biblioteca Jurídica Virtual del Instituto de Investigaciones Jurídicas de la UNAM

doctrina de la emergencia económica y su evolución en la jurisprudencia de la Corte Suprema argentina. Se analizan los diversos mecanismos normativos para hacer frente a las crisis económicas, y se pone de relieve que la declaración de emergencia no ha sido efectuada únicamente por ley formal del Congreso, sino a través de las facultades legislativas del Presidente. Se exponen los requisitos para la validez de las normas de emergencia, incluyendo la efectiva existencia de una situación de emergencia, el interés público, que la medida sea razonable y que sea transitoria. Teniendo en cuenta que los tribunales no han ejercido un adecuado control de constitucionalidad sobre las normas de emergencia, se proponen pautas para un adecuado control judicial sobre el tema bajo estudio. Se afirma que la declaración de emergencia económica y las circunstancias fácticas que le sirven de base son una cuestión sujeta a revisión judicial. Al ejercer la revisión judicial sobre este tema, se pueden considerar dos dimensiones. Por un lado, el tiempo y, por el otro, la correlación que debe existir entre una norma - la ley, la delegación legislativa o un decreto de necesidad y urgencia-y la situación de emergencia que se pretende paliar. Finalmente, se estudian las características especificas de la revisión judicial en función del tipo de norma que ha declarado la emergencia.

Palabras Clave: Emergencia económica, declaración de emergencia, facultades legislativas del presidente, cuestiones políticas, control de constitucionalidad.

\section{Table of Contents}

I. INTRODUCTION

II. The Doctrine of Economic Emergency in Argentina................ 89

III. Normative Mechanisms to Declare Economic Emergency........... 95

IV. Consequences of Economic Emergency and Permanent ECONOMIC EMERGENCY

V. Judicial Review of Economic Emergency.....

1. Specific Features of Judicial Review Depending on the Type of Regulation that Has Declared the Emergency....

2. Two Dimensions in Exercising Judicial Review over Situations of Economic Emergency

3. Judicial Review of the Existence of an Actual Situation of Economic Emergency

4. Reasonableness

\section{INTRODUCTION}

Scholars agree that in Argentina there has been a permanent economic emergency for virtually one century. In 1922, the Argentine Supreme Court in the 
Ercolano case recognized broad police power and, in particular, emergency police power. Since then, branches of government have issued many economic and social emergency regulations. Resorting to the doctrine of emergency, far from being exceptional, has virtually become the regulation. The importance of the danger entailed by this endemic situation lies in that economic emergency regulations, as any other exceptional concept, have two key elements: on the one hand, they allow for the restriction of individual rights, especially economic liberties; on the other hand, they increase the powers of one of the branches of government, namely, the Executive. This is why the use of emergency powers must be subject to clear and specific requirements to be valid, and these requirements must be met by the bodies with the authority to declare the emergency. But reality shows that these requirements have not been met in constitutional practice and, at the same time, courts have been excessively deferential to the measures adopted by the branches of government.

My purpose in this article is to study the birth of the doctrine of economic emergency in Argentina and its evolution in the cases decided by the Argentine Supreme Court. Unlike the state of siege, which had been included in the original version of the Argentine Constitution, the concept of economic emergency has had no constitutional regulation, and its contents have been outlined by the decisions of the Argentine Supreme Court. I also elaborate on the multiple regulatory mechanisms to tackle economic crises. The declaration of economic emergency is the faculty of the Argentine Congress, in principle. Throughout decades, the Executive has been adopting a more important role, so declarations of emergency were made via the legislative powers of the president - in particular, legislative delegation and decrees of "necessity and urgency"- - In addition, I will pay special attention to the requirements for economic emergency regulations to be valid, including the actual existence of a state of emergency, a public interest, that the measure be reasonable, and the provisional nature of the emergency. While these requirements have been outlined by the Argentine Supreme Court very early in time, the truth is that no appropriate judicial review over economic emergency regulations has been exercised. Because of this, I will propose some guidelines for an effective judicial review of this topic and, ultimately, to put an end to the endless emergency.

\section{The Doctrine of Egonomic Emergency in Argentina}

Constitutional law draws a dividing line between normal situations and exceptional situations. Constitutions establish a set of mechanisms regulating certain situations which are considered to be normal and foreseeable. But there are certain extraordinary situations for which standard constitutional resources may not be sufficient. In fact, the Constitution establishes a given project in connection with a normal and foreseeable situation, but it may suddenly be confronted with a different situation, which had not been foreseen, 
so it may be faced with the impossibility of ensuring its own effectiveness. As a response to this crisis situation, many constitutions incorporate an alternative way of organizing power which entails the provisional denial of the original constitutional order. ${ }^{1}$ Therefore, in the exceptional scenarios when the general regulation established in the constitution cannot be applied, exceptional measures need to be adopted. But to apply these measures the new situation must really be rare and, thus, be limited in time. ${ }^{2}$

The Argentine Constitution has not been alien to these issues, so exceptional mechanisms have been included in it to tackle exceptional situations, outside the normal periods which the Constitution is intended to govern in a usual and permanent manner. While the gamut of emergencies is extremely varied, three categories may be identified: ${ }^{3}$ war, domestic disorder, and economic crisis. Up to the constitutional reform of 1994, the Argentine Constitution had regulated only one exceptional mechanism - the state of siege - Section $23^{4}$ establishes this mechanism in the event of war (actually, "foreign attack"), and "domestic disorder".

On the contrary, unlike the state of siege, economic emergency in the beginning had no place in the formal Constitution, but it was part of customary constitutional law, which produced a series of regulations - mainly court-made in nature - in connection with the conditions and limits of the emergency law stated in the laws and decrees that had declared and applied it. ${ }^{5}$ After the 1994 constitutional reform, two additional types of exceptional mechanisms were admitted: legislative delegation and decrees of necessity and urgency, ${ }^{6}$ both of which include economic emergency. Section $76^{7}$ of the Argentine Constitution refers to "public emergency" to admit, under exceptional circumstances,

1 See Pedro Cruz Villalón, Estados excepcionales y suspensión de garantías 18 (1984).

2 See Manuel García Pelayo, Derecho Constitucional Comparado 162-63 (1999).

3 See German J. Bidart Campos, Tratado Elemental de Derecho Constitucional ArGENTINO 301 (1995).

4 Section 23 Gonstitución Nacional [Const. Nac.]: "In the event of domestic disorder or foreign attack endangering the full enforcement of this Constitution and of the authorities hereby established, any province or territory which is in turmoil shall be declared in state of siege and the constitutional guarantees shall be suspended therein. But during such a suspension the President of the Republic shall not pronounce judgment or apply penalties on his or her own. In that case, his or her power shall be limited, with respect to persons, to their arrest or transfer from one place of the Nation to another, should they not prefer to leave the Argentine territory".

5 See Néstor P. Sagúés, La Constitución bajo tensión 70 (2016).

6 See, e.g., María Angélica Gelli, Constitución de la Nación argentina. Comentada y CONCORDADA 309 (2008); Alberto R. Dalla Vía, La doctrina constitucional de la emergencia, in ColECCión de Análisis Jurisprudencial Derecho Constitucional, 757, 760 (Alberto R. Dalla Vía, dir., 2002).

7 Section 76 Const. NAC.: "Legislative powers shall not be delegated to the Executive save for issues concerning administration and public emergency, with a specified term for their exercise and according to the delegating conditions established by Congress. The expiration of the 
the legislative delegation to the Executive "with a specified term for their exercise and according to the delegating conditions established by Congress", and Section $99(3)^{8}$ sets forth that the Executive may issue decrees on grounds of necessity and urgency only "when due to exceptional circumstances the ordinary procedures provided for under this Constitution for the enactment of laws are impossible to be followed, and when regulations do not involve criminal issues, taxation, electoral matters, or the system of political parties".

Authors have established a similarity between the state of siege and economic emergency, because just like the political state of siege, established under Section 23 of the Constitution, strongly limits rights with personal content, economic emergency entails an "economic state of siege", given that the regulations declaring the economic emergency strongly restrict rights with economic content. ${ }^{9}$

After having mentioned the constitutional regulations which are the basis for economic emergency nowadays, now I want to elaborate on the origins of this mechanism in Argentina. Emergency in the economic and social arena has been connected from the beginning with the concept of police power, which was born in American law, ${ }^{10}$ and it has been alleged that it is "famously broad and equally famously vague". ${ }^{11}$ While the Argentine Constitution, like the American Constitution, has no specific provision regarding police power, the existence of a police power has been asserted since the inception of constitutionalism, both by courts and by scholars. But it must also be noted that there are constitutional provisions which are the regula-

term established in the previous paragraph shall not imply the revision of the legal relationships emerging from the regulations issued as a result of the powers delegated by Congress".

8 Section 99(3) Const. NAc.: "The Executive shall never issue provisions of legislative nature; in the event any such provisions are issued by the Executive, they shall be absolutely and irreparably null and void.

Only when due to exceptional circumstances the ordinary procedures under this Constitution for the enactment of laws are impossible to be followed, and when regulations are not about criminal issues, taxation, electoral matters, or the system of political parties, the president may issue decrees on grounds of necessity and urgency, which shall be decided by a general agreement of ministers who shall countersign them together with the Chief of the Ministerial Cabinet.

Within the term of ten days, the Chief of the Ministerial Cabinet shall personally submit the decision to the consideration of the Permanent Bicameral Committee of Congress, which shall be composed according to the proportion of the political representation of the parties in each House. Within the term of ten days, this committee shall submit its report to the plenary meeting of each House for its specific consideration and it shall be immediately discussed by both Houses. A special law enacted with the absolute majority of all the members of each House shall regulate the procedure and scope of Congress participation".

9 See Alberto B. Bianchi, La Corte Suprema ha establecido su tesis oficial sobre la emergencia económica, 1991-C La LEY 141, 150 (1991).

10 See Alberto R. Dalla Vía, Derecho constitucional económico 437 (2006).

11 See Bernadette A. Meyler, Economic Emergency and the Rule of Law, 56 DePaul L. Rev. 539, 549 (2007). 
tory basis for the police power, such as Sections $14^{12}$ and $28,{ }^{13}$ mentioning the restriction of rights and guarantees. ${ }^{14}$ Police power is generally defined as the prerogative that the Government has to regulate or limit the exercise of individual rights to ensure certain purposes, with the resulting effect of limiting individual rights to make such concrete purposes effective. There is a narrow conception of the police power, including safety, public health, or morality, ${ }^{15}$ and a broad and plenary conception, conceived in the United States, adding well-being. ${ }^{16}$ The emergency police power is contained in the second conception.

In connection with the recognition of the exercise of the broad police power, the Argentine Supreme Court has closely followed the American Supreme Court, and there even are authors who have propounded that the Argentine Supreme Court has seen the American Supreme Court as an authority. ${ }^{17}$ Scholars have stated that Argentina has experienced the same change in court opinions as the one that has taken place in the United States. At the outset, the model chosen entailed a broad protection of private property and contractual relationships - the Lochner ${ }^{18}$ case is an example-. Afterwards, the depression of the 1930s forced the adoption of emergency measures, so the age of non-interventionism started to decline rapidly with the judgments in the Home Building and Loan Association v. Blaisdell, ${ }^{19}$ Nebbia v. New York, ${ }^{20}$ and West Coast Hotel v. Parrish ${ }^{21}$ cases. $^{22}$

12 Section 14 Const. NAC.: "All the inhabitants of the Nation are entitled to the following rights, in accordance with the laws that regulate their exercise...".

13 Section 28 Const. NAC.: "The principles, guarantees, and rights recognized in the preceding sections shall not be modified by the laws that regulate their enforcement".

14 See Santiago Legarre, Poder de policía y moralidad pública 234 (2004).

15 Corte Suprema de Justicia de la Nación [CSJN] [National Supreme Court of Justice], 13/4/1869, "La Empresa 'Plaza de Toros', quejándose por un decreto expedido por el Gobierno de Buenos Aires", Colección Oficial de Fallos de la Corte Suprema de Justicia de la Nación [Fallos] (1869-7-150); 14/5/1887, "Los Saladeristas Podestá, Bertram, Anderson, Ferrer y otros contra la provincia de Buenos Aires; sobre indemnización de daños y perjuicios", Fallos (1887-31-273).

16 See, e.g., German J. Bidart Campos, Manual de la Constitución Reformada 344 (2000); Antonio M. Hernández, Las emergencias y la afectación del orden constitucional y de los derechos, in Derecho constitucional 319, 358 (Universidad ed., 2004).

17 See, e.g., Carlos Rosenkrantz, Against Borrowings and other Nonauthoritative Uses of Foreing Law, 1 Int'LJ. Const L. 269, 275-76 (2003); José S. Elias, The Constitutional Protection of Property Rights in Argentina: A Reappraisal of the Doctrine of Economic Emergency, Yale Law School Dissertations 5, 138 (2014).

18 Lochner v. New York, 198 U.S. 45 (1905).

19 Home Building and Loan Association v. Blaisdell, 290 U.S. 398 (1934).

20 Nebbia v. New York, 291 U.S. 502 (1934).

21 West Coast Hotel v. Parrish, 300 U.S. 379 (1937).

22 See, e.g., Alberto B. Bianchi, Apunte preliminar para el estudio de la historia del Derecho Constitucional, 183 El Derecho 1053-65 (1999); Alberto B. Bianchi, Historia constitucional de los 
Similarly, in Argentina at a first stage there was a "liberal" conception, favoring the effective validity of the law to the detriment of the lawmaker's regulation powers; the landmark case is Hileret..$^{23}$ At the second stage, this interpretation changed, with the idea that certain regulations, which were more or less intense, of economic rights were not inconsistent with the Constitution. This stage begins with Ercolano, ${ }^{24}$ in which a regulation limiting the prices for urban leases was validated. The trend was consolidated in Avico, ${ }^{25}$ affirming an extension in mortgage payment terms. Finally, the trend became established, first, in Cine Callao, ${ }^{26}$ admitting a law requiring owners of cinemas to include live performances, and then in Peralta, ${ }^{27}$ in which a decree limited the repayment of term deposits, paying the remainder with public debt bonds. Because of the deep economic crisis in Argentina by the end of 2001, the Argentine Supreme Court handed down decisions like Smith, ${ }^{28}$ San Luis, ${ }^{29}$ and Tobar ${ }^{30}$ which could have led to think that there was going to be a change in the case law which broadly admitted limitations to economic liberties. In the end, the Argentine Supreme Court ratified the measures to tackle the 2001 crisis in Bustos ${ }^{31}$ and Massa, ${ }^{32}$ so it can be said that the Court continued with the line of broad deference to economic regulations.

The Argentine Supreme Court clearly referred to the emergency police power in Russo, ${ }^{33}$ where it repeated its prior doctrine on this matter. ${ }^{34} \mathrm{In}$ that case, the Court clarified that it had abandoned the restrictive doctrine ad-

Estados Unidos (2013); Juan Cianciardo, Derecho constitucional de emergencia y justicia. Interpretación por analogía, LA Ley, January 28, 2005, at 1-4; Juan Cianciardo, Los límites del sistema normativo (Consideraciones a propósito de la analogía, la justicia distributiva y el derecho de propiedad), LA LEY, August 10, 2004, at 2-8.

23 CSJN, 5/9/1903, "Hileret y otro c/ Provincia de Tucumán”, Fallos (1903-98-20).

24 CSJN, 28/4/1922, "Ercolano, Agustín c/ Lantieri de Renshaw, Julieta s/ consignación”, Fallos (1922-136-161).

25 CSJN, 7/12/1934, "Avico, Oscar Agustín c/ de la Pesa, Saúl G.”, Fallos (1934-172-21).

26 CSJN, 22/6/1960, "Cine Callao”, Fallos (1960-247-121).

27 C.SJN, 27/12/1990, "Peralta, Luis A. y otro c/ Estado Nacional (Ministerio de EconomíaB.C.R.A)", Fallos (1990-313-1513).

28 CSJN, 1/2/2002, "Banco de Galicia y Buenos Aires s/ solicita intervención urgente en autos: Smith, Carlos Antonio c/ Poder Ejecutivo Nacional o Estado Nacional s/ sumarísimo", Fallos (2002-325-28).

29 CSJN, 5/3/2003, "Provincia de San Luis c/ Estado Nacional s/ acción de amparo", Fallos (2003-326-417).

30 CSJN, 22/8/2002, "Tobar Leónidas c/ E.N. M Defensa - Contaduría General del Ejercito - Ley 25.453 s/ amparo - Ley 16.986”, Fallos (2002-325-2059).

31 CSJN, 26/10/2004, "Bustos, Alberto Roque y otros c/ Estado Nacional y otros", Fallos (2004-327-4495).

32 CSJN, 27/12/2006, "Massa, Juan Agustín c/ Poder Ejecutivo Nacional", Fallos (2006329-5913).

33 CSJN, 15/5/1959, "Russo, Angel y otra c/ C. de Delle Donne E.", Fallos (1959-243-467).

34 CSJN, 27 /12/1944, "Vicente Martini e Hijos, S.R.L Infac. Ley 12.591", Fallos (1944200-450); 21/6/1957, “Juan Domingo Perón”, Fallos (1957-238-76). 
opted in old decisions, and that it came to embrace a broad and full notion of the police power, one of whose elements is emergency. The Court established that an emergency situation is a factual requirement, i.e. the existence of crisis or serious social turmoil, and that given the need to face the damage or risks created as a result of this emergency situation and to erase or mitigate its effects, the regulatory power of the Congress is broader and deeper and entails that the Government is more involved in regulating rights. The Court said that in those cases there is an intensification of government power and that mechanisms or procedures which would otherwise not be valid are actually valid. "It is not that the emergency gives rise to a new power - it simply authorizes the exercise of an already existing power with more energy. Extraordinary events... require extraordinary remedies".

Some authors have highlighted that the doctrine of emergency ceased to be justified in the exercise of the emergency police power, and the matter was to be analyzed in light of the state of necessity, ${ }^{35}$ as some started to make express reference to the fact that the steps taken were necessary to ensure the "continuity and survival" of national union. ${ }^{36}$ Sagués has made a very accurate analysis of this issue and has clearly stated that emergency law is a chapter of the necessity law, albeit subject to different requirements. ${ }^{37}$

Later on, the doctrine of economic emergency has been clearly explained by the Argentine Supreme Court in Risolía de Ocampo: ${ }^{38}$

When a situation of crisis or public necessity requires the adoption of measures to protect general interests, it is possible, without violating or eliminating any guarantees protecting economic rights, to delay, within reasonable limits, the performance of obligations stemming from acquired rights. It is not about recognizing degrees of omnipotence to the lawmaker or excluding the lawmaker from judicial review, but about not depriving the Government from any government measures deemed to be useful to bring relief to the community. Therefore, if a regulation is passed based on necessity reasons which does not deprive individuals from the economic benefits legitimately recognized or does not ignore the individuals' ownership over such benefits, but only provisionally limits the receipt of the benefits or restricts their use, there is no violation of Section 17 of the Constitution. This would just amount to a limitation imposed based on the need to mitigate or overcome a crisis situation. The Argentine constitutional system does not have any absolute rights and all rights are subordinated to the laws regulating the exercise thereof.

While the decisions of the Argentine Supreme Court have admitted the restriction of rights with economic content based on the doctrine of economic

\footnotetext{
35 See Dalla Vía, supra note 10, at. 443.

36 Peralta, Fallos (1990-313-1513).

37 SAGUÚs, supra note 5, at. 94.

38 CSJN, 2/8/2000, "Risolía de Ocampo, María José c/ Rojas, Julio César y otros s/ ejecución de sentencia (incidente)", Fallos (2000-323-1934).
} 
emergency, the truth is that it has established certain requirements for the validity of the regulations entailing any such restriction. The different requirements ensuring that exercising the power of emergency is valid were systematically discussed by the Supreme Court in 1934, in the Avico ${ }^{39}$ case, which drew on the American precedent Home Building and Loan Association v. Blaisdell. ${ }^{40}$ While these requirements have been thought for a specific case, there can be no doubt that they are useful as a guiding standard for other decisions. ${ }^{41}$ These requirements are: (1) that there be an emergency requiring the exercise of exceptional powers to protect the key interests of the society; (2) that the law be aimed at satisfying a legitimate interest and not to benefit a particular group of individuals; (3) that the remedy applied be proportionate and justified in light of the emergency; (4) that the term under the law be reasonable and do not harm any of the parties; and (5) that the law be valid for a provisional period, limited to the emergency which caused it. While these guidelines are clear to outline the contour of the constitutionality of an emergency measure, the courts have admitted the validity of many regulations which did not comply with the requirements mentioned at all.

\section{Normative Mechanisms to Declare ECONOMIC EMERGENCY}

There are different types of legal regulations which may be used to establish more intense limits to the exercise of rights based on the existence of economic emergency. In principle, the Congress is the branch of government which has the power to declare the situation of economic emergency. Under Section 76 of the Constitution, the Congress also has the power to delegate to the Executive any powers required to put an end to economic emergency. In the event there is economic emergency and the requirements for necessity and urgency are met, the Executive may use the power under Section 99(3) of the Constitution and issue a decree of necessity and urgency. ${ }^{42}$

At the beginning, the Supreme Court accepted the stricter regulation of personal rights, especially property rights and the right to enter into contracts, and the Congress passed laws regulating those matters in the exercise of the police power. The Congress passed these laws based on the current wording of Section 75(18), ${ }^{43}$ the so-called "progress clause" and Section 14, stating

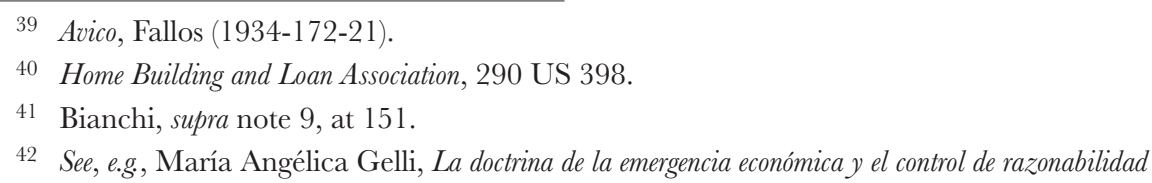
en el sistema constitucional argentino, in EMERGENCIA PÚBLICA Y REFORMA AL RÉGIMEN MONETARIO 25, 33 (Ricardo L. Lorenzetti, dir., 2002); Domingo J. Sesin, Administración Pública: actividad REGLADA, DISCRECIONAL Y TÉCNICA: NUEVOS MECANISMOS DE CONTROL JUDICIAL 321-22 (2004).

43 Under Section 75(18) Const. NAC. the Congress is empowered: "To provide for the prosperity of the country, for the progress and welfare of all the provinces, and for the advancement 
that rights are exercised in consistency with the laws regulating their exercise. In connection with the interpretation of the first of the precepts mentioned, it has been said the Supreme Court transitioned from admitting an increasing intervention of the Government on economic and social matters, based on the need to secure the general welfare and progress, to validate the remedies designed by the Legislature to solve any sectorial or general crisis. ${ }^{44}$

In many decisions, the Argentine Supreme Court affirmed the constitutionality of multiple regulations passed in exercise of the emergency police power, such as the regulation of urban lease prices, ${ }^{45}$ the extension of mortgage payment terms and the reduction of interest rates,${ }^{46}$ the stay of evictions, ${ }^{47}$ maximum prices in first-need products and goods, ${ }^{48}$ and the obligation to hire certain persons due to unemployment in a given industry, ${ }^{49}$ among many others.

There are two other normative instruments to tackle economic emergency, i.e. the legislative powers of the president: legislative delegation and decrees of necessity and urgency. As both normative devices had been used frequently, even if they were not expressly included in the Constitution, the constitutional reform incorporated them with the purpose of limiting them. Actually, during the constitutional debates in 1994, it was highlighted that one of the purposes of the reform was to generate a new balance in the operation of the three classic branches of Government - the Executive, the Legislature, and the Judiciary - and, therefore, to mitigate the presidential system, to strengthen the role of the Congress, and to attain more independence for the Judiciary. On that issue, the Supreme Court has noted that with firm and explicit wording the Argentine Constitution imposes a limitation on the president as a general regulation to pass provisions which are legislative in nature, whether on the president's own motion (Section 99[3]) or by virtue of a delegation made by the Congress (Section 76). Both sections, after establishing the principle, also state the conditions or limits under which the president is exceptionally empowered to exercise legislative functions. The wording of the constitutional text (Sections 99[3] and 76) unambiguously reflects the decision taken by the 1994 Constitutional Convention of, on the one hand, maintaining the general principle against the exercise of legislative powers by the president as a stan-

of education, drawing up general and university educational plans, and promoting industry, immigration, the construction of railways and navigable canals, the colonization of government-owned lands, the introduction and establishment of new industries, the imports of foreign capital, and the exploration of inland rivers, through laws protecting these aims and through temporary grants of privileges and stimulating rewards".

44 Gelli, supra note 42 , at 35.

45 Ercolano, Fallos (1922-136-161).

46 Avico, Fallos (1934-172-21).

47 CSJN, 15/5/1959, "Nadur, Amar c/ Borelli Francisco”, Fallos (1959-243-449); Russo, Fallos (1959-243-467).

48 Vicente Martini, Fallos (1944-200-450).

49 Cine Callao, Fallos (1960-247-121). 
dard practice and, on the other hand, to introduce more details about the exceptional conditions under which that may take place. The definition of the general regulation and the exceptional cases in the same constitutional text, as well as the procedure ultimately adopted to ensure the proper operation of both, is the correlation of two basic purposes of the constitutional deliberation: the mitigation of presidentialism and the more effective operation of the federal government. ${ }^{50}$

As explained, while legislative delegation had not been included in the 1994 constitutional reform which incorporated article 76 mentioned above, such device was admitted in the constitutional practice even if it had not been expressly provided for. Anyway, the delegations were based on Section 99(2) of the Constitution, establishing that the Executive "issues the instructions and regulations necessary for the enforcement of the laws of the nation, without altering their spirit with regulatory exceptions". These regulations are known as enforcement decrees or decrees regulating laws, and are based on Section 16 of the 1812 Cadiz Constitution. The president issues any such decrees when the application of the laws so requires, considering how accurate they were as enacted by the Congress. A minority portion of authors considered that legislative delegation was based on the doctrine of the implicit powers of the Congress, under the old Section 67(28) of the Constitution, now Section 75(32). ${ }^{51}$ At the same time, there are authors who claim that there are two spheres of legislative delegation in Argentina: a general sphere, including any delegations made to any bodies other than the Executive, based on Section 75 (32); and another specific sphere, which is the one expressly and strictly regulated under Section 76 with the purpose of controlling and mitigating presidential power. ${ }^{52}$

On this aspect, the Argentine Supreme Court issued the Delfino ${ }^{53}$ leading case, in 1927, establishing that there was a key difference between the delegation of power to make the law and to grant certain authority to the Executive or an administrative body, so as to "fill up the details" needed for the execution of such authority. Later, the Argentine Supreme Court went further to state that the regulation should be beyond the details of the law. In Prattico, ${ }^{54}$ it admitted the constitutionality of a decree which had established a minimum rise in salaries given the emergency situation that prevailed at that time, as the

50 CSJN, 4/11/2008, "Colegio Público de Abogados de Capital Federal c/ EN - PEN Ley 25.414 - dto. 1204/01 s/ amparo", Fallos (2008-331-2406).

51 Section 75(32) Const. NAc. empowers the Congress: "To make all appropriate laws and regulations to put into effect the aforementioned powers, and all other powers granted by this Constitution to the Government of the Argentine Nation". See Alberto B. Bianchi, La Delegación legislativa. Teoría de los reglamentos delegados en la Administración Pública 51-2 (1990).

52 See Santiago M. Castro Videla \& Santiago Maqueda Fourcade, La delegación legislativa en la Corte Suprema de Fusticia de la Nación, 2018-III Jurisprudencia Argentina 2, 15 (2018).

53 CSJN, 20/6/1927, "Delfino y Cía.", Fallos (1927-148-430).

54 CSJN, 20/5/1960, "Prattico, Carmelo y otros c/ Basso y Cía.", Fallos (1960-246-345). 
"legislative policy" had been "clearly established". Afterwards, the Supreme Court recognized that its decisions had admitted the delegation of legislative powers beyond the regulatory power in the current wording of Section 99(2) of the Argentine Constitution, such delegation being subject to the limits of Section 28 of the Constitution, i.e. reasonableness. ${ }^{55}$ The admission of legislative delegation to the Executive has deepened in time, being admitted with increasingly broader standards. In Cocchia,${ }^{56}$ the Court affirmed the validity of a decree amending a port activity collective bargaining agreement, as it observed the "legality block". In connection with this first stage before the constitutional reform, Sagüés has clearly said that in the Argentine Supreme Court there was a solid jurisprudential trend that "based on puns and normative costumes, consents to actual delegations of congressional powers to the president, covered by the blanket of the exercise of regulatory powers" ${ }^{57}$

As it was standard practice to make delegations, the 1994 constitutional reform admitted the legislative delegation and subjected it to multiple requirements. The Constitution states that "legislative delegation to the Executive is forbidden except for certain matters in connection with administration or public emergency, with a fixed term for its exercise and within the basis for the delegation established by the Congress". What we see here is that the Constitution establishes a general principle forbidding the delegation to the Executive and, subsequently, establishes the exceptions that may be admitted. For the delegation to be valid, three basic requirements must be met: that the delegation be limited to administration or public emergency matters; that the decrees be issued within the term set for their exercise; and that the decrees adjust to the delegation basis established by the Congress. Section 100(12) adds a fourth requirement - that any such decrees be affirmed by the Chief of the Ministerial Cabinet and subject to the control by the Argentine Permanent Bicameral Committee. Especially in connection with the term "public emergency", authors have criticized that its meaning is not clear, ${ }^{58}$ as resorting to public emergency is "no limit to the Argentine institutional reality". 59 The term "public emergency" is an indeterminate legal concept, and it may cover multiple types of emergencies, such as natural, political, military, administrative, but also economic and social emergencies.

55 CSJN, 17/5/1973, "Potosí S.A. y otros c/ Nación”, Fallos (1973-285-443); 17/3/1988, "D’Anna, Carlos Alberto y otros c/ Siam Sociedad Industrial Americana Maquinarias S. A.", Fallos (1988-311-290).

56 CSJN, 2/12/1993, "Cocchia, Jorge D. c/ Estado Nacional y otro", Fallos (1993-3162624).

57 See Néstor P. Sagüés, Legislación del Poder Ejecutivo detraída del Poder Legislativo (A propósito de los decretos "delegados" y de "necesidad y urgencia"), 1-2 Revista DE Derecho Bancario y de la ActiviDAD FinANCIERA 97, 108 (1991).

58 See Rodrigo Sánchez Brígido, Control de constitucionalidady delegación legislativa, 12 DiscusioNES 81, 83 (2013).

59 See Daniel A. Sabsay \& José Onaindia, La Constitución de los argentinos 255 (2004). 
But it cannot be said that the guidelines in the Constitution have been useful to limit the way in which the legislative delegation has been used. Law No. 25561 was enacted to tackle the 2001 crisis and, under the provisions of Section 76 of the Constitution, declared the public emergency on social, economic, financial, and foreign exchange grounds, and delegated to the Executive various powers for two years. However, such regulation has been extended nine times and has been valid until December 2017, even when the declaration of social emergency was extended to December 2019. It is a problem that the regulation has been in force during an extremely long period, but authors have also highlighted that the delegated powers were dangerously close to the prohibition under Section 29, ${ }^{60}$ providing that the Congress cannot give all public power to the Executive. ${ }^{61}$

Another mechanism used to tackle economic emergency is the decree of necessity and urgency. As explained, this mechanism had not been included in the Constitution until the 1994 constitutional reform. It may be said that decrees of necessity and urgency were forbidden in the beginning. Afterwards, they were admitted, but only as an exception. Their use in practice, however, is regular. The Executive used this tool in the past, for example, in the creation of the "Austral" currency in 1985 with the purpose of tackling the economic crisis in the country at that time. ${ }^{62}$ Another example: in 1990 a decree was issued ordering the repayment of term deposits and the surplus was paid with external bonds. ${ }^{63}$ Both decrees were affirmed by the Supreme Court. In Peralta, the Supreme Court held that the decree was constitutional because of the "serious social risk" situation and the "generalized economic turmoil". The constitutional reform incorporated Section 99(3) with the purpose of regulating these decrees so that their use was limited. First, a general prohibition against their use was provided for — "the Executive Power shall in no event issue provisions of legislative nature" - and it admitted issuing a decree based on necessity and urgency "only when due to exceptional circumstances the ordinary procedures established under this Constitution for the enactment of laws are impossible to be followed, and when regulations do not involve crimi-

60 Section 29 Const. NAC.: "Congress may not vest on the Argentine Executive — nor may the provincial legislatures vest on the provincial governors - any extraordinary powers or the total public authority; it may not grant acts of submission or supremacy whereby the life, honor, or wealth of the Argentine people will be at the mercy of governments or any person whatsoever. Any acts of this nature shall be utterly void, and shall render those who formulate them, consent to them or sign them, liable to be sentenced as infamous traitors to their fatherland".

61 Alberto B. Bianchi, La emergencia desjuridiza. La emergencia absoluta desjuridiza absolutamente (análisis de la ley 25.587), 187 Debates de Actualidad 23 (2002). See also Law No. 27540 which declared the public emergency on economic, financial, fiscal, administrative, social security, tariff, energy, health and social grounds, and delegated to the Executive various powers, until December 31, 2020.

62 CSJN, 20/4/1989, "Porcelli, Luis A. c/ Banco de la Nación Argentina s/ cobro de pesos", Fallos (1989-312-555).

63 Peralta, Fallos (1990-313-1513). 
Esta revista forma parte del acervo de la Biblioteca Jurídica Virtual del Instituto de Investigaciones Jurídicas de la UNAM

nal issues, taxation, electoral matters, or the system of political parties". The Constitution also set forth a procedure for the ratification of those decrees by the Congress. In such procedure the Permanent Bicameral Committee must be involved, and next the matter must be treated by each of the houses of the Congress, the House of Representatives, and the Senate. However, authors have seriously criticized this regulation: " $\mathrm{t}]$ he way in which the Argentinian constitution regulates emergency decrees is probably one of the worst in Latin America" because "nothing in the constitution deters the president from using emergency powers in an unjustified way if he has the required majorities in one of the houses of congress". ${ }^{64}$ Sagüés also considers that the drafting of the section is faulty, as it is an incomplete regulation, which does not design the final procedure of decrees of necessity and urgency. ${ }^{65}$

\section{Consequences of Economic Emergency and Permanent Economic Emergency}

Economic emergency in Argentina, far from being an exceptional situation, is normal and standard. Virtually all authors agree on this point. Authors specializing in constitutional law, ${ }^{66}$ administrative $\operatorname{law}^{67}$ and other areas ${ }^{68}$ agree that Argentina suffers from permanent emergency, and have proposed putting an end to it, as the effects of such emergency are devastating. ${ }^{69}$ It has been claimed that emergency is an everyday reality, and that the exceptional law has become standard practice,${ }^{70}$ so the concept of "emergency" has been used and abused. ${ }^{71}$

64 See Carlos Rosenkrantz, Romans (not the Fudges) Have the Solution, 89 Tex. L. Rev. 1557, 1581 (2011).

65 See Néstor P. Sagüés, Oposición entre un decreto de necesidad y urgencia y una ley de delegación legislativa, 2003-II Jurisprudencia Argentina 1313 (2003).

66 See, e.g., Bianchi, supra note 9, at 141; Gregorio Badeni, Emergencia económica y Estado de Derecho, 2007-A La Ley 1039 (2007); Alberto R. Dalla Vía, La doctrina constitucional de la emergencia y el derecho de propiedad, La Ley: Suplemento Especial 'La emergencia y el caso Massa', 48 (2007); María Angélica Gelli, El caso 'Massa': fin de un capítulo en la pesificación de los depósitos bancarios, 2007-A La Ley 1120 (2007); Alejandro Pérez Hualde, La permanente invocación de la emergencia como base de la crisis constitucional, 2006-A LA LEY 872 (2006); Jorge R. Vanossi, El mar no perdona, 2003-C LA LEY 950 (2003).

67 See, e.g., Pedro J. J. Coviello, El control judicial de la emergencia, 2009-I JurisPrudencia ArGENTINa 1086 (2009); Agustín Gordillo, El Estado de Derecho en estado de emergencia, in EmERGEncia PÚBlica Y REFORMA AL RÉGIMEN MONETARIO 53 (Ricardo L. Lorenzetti, dir., 2002).

68 See, e.g., Ricardo A. Guibourg, Norma, coyuntura y emergencia, 2003-E LA LEY 1061 (2003); Ricardo L. Lorenzetti, Los contratos ante la emergencia económica, 1993-G LA LEY 811 (1993).

69 See Ricardo L. Lorenzetti, Nunca más: Emergencia económica y derechos humanos, 2003-A LA LEY, 1207 (2003).

70 See Tomás Hutchinson, La actual crisis y su solución desde el derecho, RevisTa DE Derecho PúBlico, La Emergencia económica (segunda parte), 343 (Tomás Hutchinson, dir., 2002).

71 See Miguel A. Ekmekdjian, Manual de la Constitución Argentina 279 (2008). 
The specific issue with this matter is that economic emergency, like some other exceptional mechanisms, has two distinct features: certain prerogatives of power are increased, reinforcing a given body of power; and they create a restriction on individual liberties, rights, and guarantees, especially economic liberties. ${ }^{72}$ Article 16 of the 1789 Declaration of the Rights of Man and of the Citizen provides that "[a] society in which the observance of the law is not assured, nor the separation of powers defined, has no constitution at all". Economic emergency precisely undermines these two aspects. On the one hand, serious restrictions of these rights have been admitted throughout decades, which significantly harms the rights recognized under the Constitution. On the other hand, the principle of the separation of powers has been affected, as economic and social crises have given rise to more demands from the Government, and the Executive has adopted a key role in the adoption of measures to tackle the economic emergency. ${ }^{73}$ Actually, the limitation on economic liberties, mainly the right to property and the liberty to enter into contracts, was made by passing laws. Afterwards, the limitations took effect mainly through decrees of necessity and urgency, and legislative delegation. Along this line, it has been highlighted that economic emergency alters institutional roles: "This is made for the Executive, as it is the only body that makes it on time. The Legislature affirms the measure. Sometimes, the Judiciary amends its effects". ${ }^{74}$ That is why authors are right in pointing that the state of emergency is inversely proportional to the rule of law. ${ }^{75}$ When the Executive resorts to the doctrine of economic emergency, legal uncertainty grows exponentially in the rule of law. ${ }^{76}$ While the Argentine Constitution is a rigid constitution, in Bryce's terms, ${ }^{77}$ as a result of Argentina's "endemic" economic emergency, we have come to have a flexible Constitution system, which may be modified at the Congress's or the Executive's discretion. ${ }^{78}$ It has been said that the doctrine of economic emergency has been systematically repeated to justify the submission of the Constitution to political powers. ${ }^{79}$

Another matter that needs to be considered in connection with the evolution of the doctrine of economic emergency in Argentina is that since the

72 See, e.g., Bidart Campos, supra note 3, at 301; Hernández, id. supra note 16, at 322; EkmEkdjian, $i d$., at 279; Oren Gross \& Fionnuala Ní Aoláin, Law in times of Crisis: emergency POWERS IN THEORY AND PRACTICE 58 (2006).

73 See Juan S. Ylarri, La división de poderes en la emergencia económica en Argentina, 32 Cuestiones Constitucionales 235 (2015).

74 See Pedro J. Frías, ¿Separación de poderes o qué?, La Ley, November 3, 1992, at 2.

75 See, e.g., Dalla Vía, supra note 6, at. 757; Daniel A. Sabsay \& Cristián H. Fernández, El fomento de las industrias y la emergencia económica, 2016-D LA LEY 886 (2016).

76 Roberto J. Vernengo, Nota sobre el recurso a la emergencia como procedimiento derogatorio, 2003-E LA LEY 1084 (2003).

77 See James Bryce, Constituciones flexibles y constituciones rígidas (CEPC ed., 2015).

78 See Bianchi, supra note 61, at 23.

79 See Susana Cayuso, La emergencia económica y la Constitución. Crónica de un pasado y presente contradictorios y de un futuro incierto. En busca de los controles perdidos, 2005-C LA LEY 1319, 1321 (2005). 
Ercolano case, which recognized the emergency police power, and its deeper discussion in Avico, emergency cases usually had to do with social or economic and social emergency, or cases in which the society was affected, but the matter was not extended to the Government itself.

In many decisions the Argentine Supreme Court declared the constitutionality of many regulations passed in exercising the emergency policy; ${ }^{80}$ extension of lease contracts, i.e. stay of the lessor's right to obtain the delivery of the leased property and a reduction in lease payments agreed upon by the parties; ${ }^{81}$ extension of mortgage payment terms, i.e. stay of "any legal remedies or actions against debtors"; 82 stay of evictions, ${ }^{83}$ maximum prices for first-need products or goods, ${ }^{84}$ among other matters. After that line of court decisions - the Peralta case may be considered square one- the emergency police power was extended also to the emergency affecting the Government itself, especially considering public deficit. Also, as we have already seen, a large number of powers of various types were granted upon the Executive. In other cases, the Argentine Supreme Court validated the system to fix salary increases by the Executive and, therefore, the abrogation of conventional rules regulating wages ${ }^{85}$ the limitation of the repayment of term deposits, paying the excess with external bonds; ${ }^{86}$ the consolidation of the Argentine Government's debts; ${ }^{87}$ the reduction in public employees's salaries, ${ }^{88}$ and when the salary decrease ceased, the return of a certain percentage of the discounted sums with the delivery of public securities ${ }^{89}$ the staying of the enforcement of court judgments and arbitral awards ordering the payment of a sum of money entered against the Argentine Government ${ }^{90}$ and the "pesification" of public debt bonds issued by the Argentine Government in U.S. dollars, ${ }^{91}$ among others.

80 Russo, Fallos (1959-243-467).

81 Ercolano, Fallos (1922-136-161).

82 Avico, Fallos (1934-172-21).

83 CSJN, 1/3/1946, "Cello de Ciarrapico, Eugenia C. c/ Marino, Cayetano", Fallos (1946204-195).

84 Vicente Martini, Fallos (1944-200-450).

85 CSJN, 7/8/1990, "Soengas, Hector Ricardo y otros c/ Ferrocarriles Argentinos", Fallos (1990-313-664).

86 Peralta, Fallos (1990-313-1513).

87 CSJN, 22/12/1993, "Hagelin, Ragnar c/ Poder Ejecutivo Nacional s/ juicio de conocimiento", Fallos (1993-316-3176); 19/10/1995, "Cacace, Josefa Erminda c/ Municipalidad de la Ciudad de Buenos Aires s/ accidente - Ley 9688", Fallos (1995-318-1887).

88 CSJN, 2/6/2000, "Guida, Liliana c/ Poder Ejecutivo Nacional s/ Empleo público", Fallos (2000-323-1566).

89 CSJN, 2/12/2004, "Colina, Rene Roberto-Yapura, Sergio Daniel-Vargas, Cesar Eduardo y otros c/ Estado Nacional", Fallos (2004-327-5318).

90 CSJN, 27/12/1990, "Videla Cuello, Marcelo c/ La Rioja, Provincia de", Fallos 1990313-1638).

91 CSJN, 5/4/2005, "Galli, Hugo Gabriel y otro c/ P.E.N. - Ley 25.561 - dtos. 1570/01 y 214/02 s/ amparo sobre Ley 25.561”, Fallos (2005-328-690). 


\section{Judicial Review of Economic Emergency}

The existence of a continued application of economic emergency regulations would not have been possible without the deference of the courts. Throughout decades, the Argentine Supreme Court has tolerated the measures adopted by the branches of government based on economic emergency, admitting in some cases clear violations of rights protected under the Constitution, even if the requirements for the declaration of the emergency were not met.

This issue has been identified by the Court itself, when it said that the history of its decisions shows an extremely broad approach regarding admissible restrictions, ${ }^{92}$ and that this is an approach requiring correction, as its institutional effects have been devastating, given that the rule of law needs a stable system of regulations at the base and not its disregard due to urgent needs. ${ }^{93}$ The study of the main decisions by the Argentine Supreme Court regarding the extent to which the right to property may be affected based on economic emergency shows the clear preponderance of an interpretation tolerating broad restrictions. ${ }^{94}$ Authors have said that the review of the reasonableness of economic emergency regulations made by the Argentine Supreme Court has been weak ${ }^{95}$ and shallow. ${ }^{96}$

Historically, courts have been deferent to the measures adopted to tackle economic emergencies. ${ }^{97}$ The deference to such regulations has been so extreme, however, that it has been even said that economic emergency is a covered political matter. Bianchi actually maintains that while economic emergency has not been dealt with by the courts as a non-justiciable political question, the Argentine Supreme Court has never analyzed in depth the real causes of the economic emergency, or the reasonableness of the measures in light of the causes, so the Court has acted as if this matter would have been excluded from judicial review. ${ }^{98}$

In this context, I believe it is appropriate to propose some guidelines for an appropriate judicial review of this matter. First, it is necessary to highlight that the declaration of economic emergency and the factual circumstances underlying such declaration is a question subject to judicial review, and these

92 Massa, Fallos (2006-329-5913), Lorenzetti, separate opinion; 15/3/2007, "Rinaldi, Francisco Augusto y otro c/ Guzman Toledo, Ronal Constante y otra s/ Ejecución hipotecaria", Fallos (2007-330-855), Lorenzetti and Zaffaroni, separate opinion.

93 CSJN, 18/12/2007, "Longobardi, Irene Gwendoline y otros c/ Instituto de Educación Integral San Patricio S. R. L.”, Fallos (2007-330-5345), Lorenzetti, dissenting.

94 Massa, Fallos (2006-329-5913), Lorenzetti, separate opinion.

95 See, e.g., GeLLI, supra note 6, at 309; Cayuso, supra note 79, at 1323.

96 See Alberto B. Bianchi, Control de Constitucionalidad 39 (2002).

97 See Gustavo Maurino \& Ezequiel Nino, Economic and social rights and the Supreme Court of Argentina in the decade following the 2001-2003 crisis, in Economic AND Social Rights AFter the Global Financial Crisis 299, 322 (Aoife Nolan, ed., 2014).

98 See Bianchi, supra note 6, at 284. 
issues are not non-justiciable political questions. ${ }^{99}$ While the Argentine Supreme Court has admitted that the situation of economic emergency and its declaration are subject to review, I agree with the authors who believe that this issue has been discussed by the Supreme Court as if it were a covered political matter, as the Supreme Court has dogmatically accepted the existence of the emergency as presented by political powers in all instances. My position is that the situation of economic emergency and its declaration through a regulation are a justiciable question. This means that a court has the power to declare that an emergency regulation is unconstitutional when an alleged emergency situation is not such, i.e. when it is false, and therefore may be subject to objection under the Constitution. The consideration of the reality made by the Legislature or, if applicable, the Executive faced with a situation or event considered to be an emergency situation or an event is a justiciable question.

Now, considering the judicial review of economic emergency regulations, one needs to ask whether, in the event of any exceptional circumstances, it is the duty of courts to be more deferent to the measures adopted by the public authorities than during normal times, if it is appropriate to exercise a more intense control or, ultimately, if the judicial review should be as strict during normal times as during exceptional times. Considering the serious excess incurred on this matter during decades, I believe that the judicial review over these regulations should be stricter than during normal times. Not only because the economic emergency admits a higher restriction of economic rights and entails a temporary limitation of the principle of separation of powers, but also because historically there has been abuse by branches of government and scarce judicial review.

\section{Specific Features of Judicial Review Depending on the Type of Regulation that Has Declared the Emergency}

There are certain specific features of judicial review depending on the type of regulation that has declared the emergency. There will be differences depending on whether the regulation is a law in a formal sense, a legislative delegation, or a decree of necessity and urgency.

In connection with the declaration of economic emergency through a formal law, we need to remember that laws enacted by Congress are presumed to be constitutional. That said, this presumption does not entail being absolutely deferent to the lawmaker's judgment. This idea of "full deference" must be rejected, as it may entail considering that the factual circumstance which is the basis to declare the economic emergency is virtually a non-justiciable political question. On the contrary, I believe that the judge may assess the factual circumstances alleged by the lawmaker, without replacing the

99 See Juan S. Ylarri, La emergencia económica. El control de constitucionalidad de la Situación de emergencia económica y su Declaración Normativa (2019). 
lawmaker's discretion. The judge may assess in a specific case that there exist factual circumstances to declare the economic emergency. This does not entail considering that the law is unconstitutional prima facie or that the judges should declare that the regulation is unconstitutional if in doubt. If the judge considers that the factual circumstance does not exist, the judge may hold that the regulation is unconstitutional.

Regarding the legislative powers of the president, delegated decrees and decrees of necessity and urgency, I am of the opinion that these decrees must be subject to a different constitutionality test, other than extreme deference to the decision of political bodies. The "restrictive interpretation" is a judicialreview standard which I consider appropriate for these regulations, taking into account that the Constitution clearly states that these regulations are forbidden. The exercise of legislative powers by the Executive is exceptional and any regulations providing for that exercise must be interpreted restrictively. But a strict scrutiny to consider any such regulations unconstitutional would not be apposite, as one cannot disregard that we are discussing a normative mechanism established in the Constitution, albeit with several limitations. The restrictive interpretation entails that he or she who claims that a decree with legislative content is unconstitutional always has the burden of proving so. But in the event of reasonable doubt regarding its constitutionality, the court must declare that any such regulations are unconstitutional. This is because, in principle, the legislative powers of the president are restricted and their admission is subject to extremely stringent conditions. The Legislature is the body tasked with legislating. The Executive may only legislate in very rare situations. Therefore, the Executive must always provide grounds for the factual circumstances which make it permissible to issue a decree with the force of law. If not, in the event that there is doubt about whether the factual circumstances make it permissible to issue a decree or not, any such regulation will be deemed unconstitutional. Regulations are not always and in every case presumed to be unconstitutional. He or she who alleges must prove. But if there is doubt, the regulation with legislative content must be held to be unconstitutional. Regulations are not always and in every case presumed to be unconstitutional; only in the case of doubt. A large part of authors agree that this restrictive standard must be applied when analyzing the legislative powers of the president. ${ }^{100}$ Other authors believe that the exercise of legislative powers by the Executive is an exception, ${ }^{101}$ so they must be subject to "close

100 See, e.g., Alberto R. Dalla Vía, Control de la emergencia y la legislación delegada, 187 DeBATES DE Actualidad, 15, 17 (2002); Daniel A. Sabsay, Control de la facultad del PEN de dictar decretos de necesidad y urgencia, 2010-A LA LEy 278, 280 (2010); José S. Elias, Urgencia, necesidad y decretos, LA Ley: Suplemento Universidad de San Andrés, December 21, 2010, at 7; Santiago M. Castro Videla \& Santiago Maqueda Fourcade, Aproximación al principio restrictivo en el dictado e interpretación de regulaciones económicas. Aportes sobre sus fundamentos, alcances y aplicaciones, 510 EL DERECHO ADMINISTRATIVO 25, 28 (2017).

101 See María Angélica Gelli, La revisión judicial de la normativa de emergencia, entre las coordenadas del control de constitucionalidad, La Ley: Suplemento Constitucional, August, 2010, at 45. 
scrutiny"102 or "careful examination". 103 Anyway, some authors maintain an opposing position. Barra and Licht assert that the constitutional reform of 1994 designs a new set of functional relations between the President and Congress, notably accentuating the leading role of the former, while strengthening the controlling role of the latter. They believe that a restrictive interpretation of the legislative power of the president denatures the system and tends to nullify, in practice, the institutional progress achieved with the 1994 reform. ${ }^{104}$ I consider this approach wrong, as it cannot be said that the 1994 constitutional reform has been intended to underscore the leading role of the Executive, as constitutional debates clearly show.

Also, the Argentine Supreme Court has outlined several guidelines to control the legislative powers of the president. The most important case in connection with legislative delegation, establishing the criteria to be followed to analyze a legislative delegation, is Colegio Público de Abogados de la Capital Federal. ${ }^{105}$ In this case, the Argentine Supreme Court made express reference to the decisions rendered by the U.S. Supreme Court and held that a key consideration for the validity of the activity performed in the exercise of delegated powers is the creation by the Congress of an intelligible and clear standard or guideline to which the president must be subject. In connection with the basis that the Congress must establish to delegate to the Executive, it held that a delegation without basis is forbidden. And it also stated that when the basis is drafted in a very generic and indeterminate way, the delegated activity will be validated by the courts if the interested party overcomes the burden of establishing that the provision issued by the president realizes the specific legislative policy foreseen by the Congress to pass the pertaining delegation clause. This is how the Argentine Supreme Court resorts to the notion of "restrictive interpretation" mentioned before. This issue was the subject matter of two subsequent cases, Y.P.F. ${ }^{106}$ and Provincia de Santa Fe. ${ }^{107}$

With regard to decrees of necessity and urgency after the 1994 constitutional reform, in Rodríguez ${ }^{108}$ the Argentine Supreme Court virtually abandoned the judicial review of these decrees, arguing that Section 99(3) establishes a

102 See Roberto Gargarella, In Search of Democratic Fustice-What Courts Should Not Do: Argentina, 1983-2002, in Democratization and the Judiciary. The Accountability Function of Courts in New Democracies 132, 139 (Siri Gloppen, Roberto Gargarella \& Elin Skaar, eds., 2004).

103 See Elias, supra note 17, at 422.

104 See Rodolfo Barra \& Miguel Licht, Los decretos de necesidady urgencia, 2016-C La LEY 1157 , 1159 (2016).

105 Colegio Público de Abogados de Capital Federal, Fallos (2008-331-2406).

106 C.SJN, 3/7/2012, "Y.P.F S.E. c/ Esso S.A.P.A s/ proceso de conocimiento", Fallos (2012-335-1227).

107 CSJN, 24/11/2015, "Provincia de Santa Fe c/ Estado Nacional s/ acción declarativa de inconstitucionalidad", Fallos (2015-338-1389).

108 CSJN, 17/12/1997, “'Rodríguez, Jorge' en: 'Nieva, Alejandro y otros c/ Poder Ejecutivo Nacional", Fallos (1997-320-2851). 
specific control by Congress of the decrees of necessity and urgency, for which reason the intervention of the Judicial Power is not justified. Then it handed down many judgments in connection with the aforementioned decrees, admitting its jurisdiction to assess the existence of a state of necessity permitting the issuing of decrees of necessity and urgency. ${ }^{109}$ In some cases, the Court declared the unconstitutionality of the decrees because the problem was an industrial crisis and not one affecting the society at large ${ }^{110}$ or because the decrees were about tax matters, which is forbidden under the principle of legality. ${ }^{111}$ In another case, the Court admitted the reduction in public employees's salaries. ${ }^{112}$

Another important matter is the impact of the ratification by Congress of a decree issued by the Executive. The procedure and the extent of the Congress's intervention were regulated as late as in 2006, when Law No. 26122 was issued. In connection with the surveillance function of the Argentine Congress, the law sets forth that "the rejection of the pertaining decree by both houses of Congress entails its abrogation". I believe that the regulatory law is unconstitutional, as a decree will only be abrogated if both houses of Congress reject it. Requiring the rejection by both houses of Congress of a decree exercising legislative powers is a contradiction, as the passing of a law by the Congress requires the approval of both houses, under the provisions of Section 78, Argentine Constitution. In addition, it is appropriate to clarify that while a decree of necessity and urgency ratified by the Congress has more democratic legitimacy than a decree without that ratification, the truth is that it may happen that the Executive issued a decree of necessity and urgency when the exceptional circumstances are not present, and that the Legislature anyway validates any such decree. In any event, even when there has been approval by the Congress in connection with a decree of necessity and urgency, the decree will be subject to judicial review. Political review is also important, to the extent that it permits the Legislature to invalidate a decree. But just as the judicial review of emergency laws is admitted to verify that the emergency is real, judicial review of the actual existence of a necessity and urgency in the issuance of

109 CSJN, 19/8/1999, "Verrocchi, Ezio Daniel c/ Poder Ejecutivo Nacional - Administración Nacional de Aduanas s/ acción de amparo", Fallos (1999-322-1726; 1/9/2003, "Cooperativa del Trabajo Fast Limitada c/ Poder Ejecutivo Nacional”, Fallos (2003-326-3180); 19/5/2010, "Consumidores Argentinos c/ EN - PEN - Dto. 558/02-SS - Ley 20.091 s/ amparo Ley 16.986", Fallos (2010-333-633); 27/10/2015, "Asociación Argentina de Compañías de Seguros y otros c/ Estado Nacional - Poder Ejecutivo Nacional s/ nulidad de acto administrativo", Fallos (2015-338-1048).

110 CSJN, 2/8/2000, "Risolía de Ocampo, María José c/ Rojas, Julio César y otros s/ ejecución de sentencia (incidente)", Fallos (2000-323-1934).

111 CSJN, 6/6/1995, "Video Club Dreams c/ Instituto Nacional de Cinematografia", Fallos (1995-318-1154); 17/3/1998, "Spak de Kupchik, Luisa y otro c/Banco Central y otro", Fallos (1998-321-366).

112 Guida, Fallos (2000-323-1566). 
the decrees, even if ratified by the Legislature, should also be admitted. While it is appropriate that courts give more deference to decrees of necessity and urgency validated by the Congress - especially if ratified by both houses-, the point is that legislative ratification does not prevent the review by courts for an actual case of necessity and urgency. It is important to remember that the validation of a decree of necessity and urgency is about a regulation in force which has been unilaterally issued by the Executive, in whose preparation there was no appropriate public participation or communication.

\section{Two Dimensions in Exercising Fudicial Review over Situations of Economic Emergency}

In exercising judicial review over situations of economic emergency and its normative declaration, two dimensions may be considered. First, timing, and, second, the correlation that must exist between a regulation - law, legislative delegation, or a decree of necessity and urgency - and the emergency situation it is intended to fight against.

I believe that the time of validity of a regulation may be considered as a factor to establish the scope of the judicial review of an emergency regulation. We need to remember that emergency must be temporal and subject to a brief term, even if this has not been the case of Argentina. Four situations may be identified. First, there is the situation of the scope of the judicial review of the emergency situation at the beginning of the emergency. While the legislative powers of the president must always be interpreted restrictively, in connection with economic emergency formal laws, it may be maintained that at first the courts should be deferential to the regulation adopted and the factual circumstances alleged. This matter has been discussed by Chief Justice Rosenkrantz "more deference should be granted to the government when the emergency has just started than when the emergency has been ongoing for a significant period of time". 113

The fact that courts should have different approaches does not entail that the branches of government are exempt from justifying their decisions. While at this stage it is not appropriate to demand full evidence by political powers with respect to the emergency situation invoked to resort to the exceptional emergency law, in adopting these measures it is necessary to somehow establish the exceptional situation. It is not enough that the Government dogmatically states that there is an emergency. It is true that economic emergency situations require quick governmental action. But, even when these exceptional circumstances demand an urgent solution, any decisions adopted must be reasoned, and must be based on the factual circumstances they seek to fight against. In light of the loose judicial review historically exercised, it is appropriate to state that in the case of emergency regulations the need for justification is all the

113 Rosenkrantz, supra note 64, at 1567. 
more necessary. To start with, the Government must provide arguments for the existence of the factual circumstance of the emergency; in the event of a law, in the message of the bill, in the work in congressional committees, and during the congressional debate. In connection with the legislative powers of the president, in the grounds of the measure, as well as in the file for the measure. This will force the Congress or, if appropriate, the Executive to make a deeper analysis of the existence of the emergency factual circumstance and the measures aimed at fighting against it. This need to provide grounds will somehow result in better analysis of the measures adopted and, therefore, in better regulation.

First, considering this requirement to provide grounds, it is questionable that the Argentine Supreme Court has many times said that the situation of economic emergency is public and evident, ${ }^{114}$ as in court proceedings evident events are exempt from evidence. I believe that it would not be enough to merely admit the situation of economic emergency based on that statement, but that it is appropriate to demand from branches of government more grounds regarding the actual existence of a situation of emergency, and from the courts, a deeper analysis of the matter. That the judges get to know the details of a given situation of emergency is important not only to verify the existence of a true factual circumstance of emergency, but also to establish the end of any such emergency and to review the reasonable relationship between the emergency measure adopted and the emergency situation alleged.

Second, it is necessary to remember that for an emergency law to be valid, it is necessary that it be temporary, i.e. that it be subject to a given term. As the economic emergency is an exceptional situation, it is reasonable to demand that the term be short. It may happen that a regulation intended to tackle the economic emergency is repeatedly extended. In this case, it is appropriate to say that the regulation deserves a higher intensity of judicial review, so the deference to what the political powers have decided decreases. When an emergency measure is extended, further evidence establishing the situation of emergency must be furnished.

Third, it may happen that the economic emergency regulation continues to be extended in time, but afterwards the situation of emergency no longer exists. In the event that the situation of emergency invoked in a given regulation afterwards disappears, it would be appropriate to invalidate the regulation based on the lack of a constitutional cause that justifies its validity, as the powers granted would lack the exceptional circumstances justifying it. This means that the declaration of unconstitutionality after the facts is admitted. The Argentine Supreme Court has admitted the possibility of declaring the unconstitutionality after the facts of a regulation in several cases. ${ }^{115}$ In connection with the eco-

114 See, e.g., Ercolano, Fallos (1922-136-161); Avico, Fallos (1934-172-21); "Inchauspe Hnos., Pedro c/ Junta Nac. de Carnes", Fallos (1944-199-483); Nadur, Fallos (1959-243-449); Russo, Fallos (1959-243-467); Peralta, Fallos (1990-313-1513); Bustos, Fallos (2004-327-4495).

115 CSJN, 3/5/1979, "Valdéz, Julio H. c/ Cintioni, Alberto D.”, Fallos (1979-301-319); 16/12/1993, "Vega, Humberto A. c/ Consorcio de Propietarios Edificio Loma Verde y otro", 
nomic and social emergency, the Argentine Supreme Court held in Mango ${ }^{116}$ that the crisis that had justified a housing emergency law did not exist anymore, so the regulation became unconstitutional.

Fourth, it is necessary to consider the possibility that the emergency regulation is evidently inadequate. It could happen that the emergency regulation be extended for a long period of time, but that the situation of emergency persists. The unreasonableness of the means applied on the basis of inadequacy should be assessed. If the emergency regulation remains valid for a long period and the means applied are not adequate to tackle a given crisis, the review of the reasonableness of the regulation may determine that the measure is not adequate to attain the purpose it seeks. In any case, courts should exercise judicial review with particular care on this matter.

Moreover, I am of the opinion that there must be a relationship of adequacy - or "connection of sense" - in the wording of the Spanish Constitutional Court, between the emergency measure adopted and the emergency situation invoked. ${ }^{117}$ In fact, it could happen that measures be adopted which are allegedly aimed at tackling a specific economic emergency situation, but in the absence of proper grounds, the courts may hold that the measures adopted have no adequacy relationship or connection of sense, directly or indirectly, with the specific factual situation that the regulation is intended to face. On this point, it is appropriate to mention the case of Law No. 25561. In 2002, such regulation declared the public emergency on social, economic, administrative, financial, and foreign exchange matters, and delegated the powers included in the law to the Argentine Executive until the end of 2004. The regulation was in force until December 2017. Regardless of whether the means used were adequate to the purpose sought by the regulation, more than fifteen years after it was passed, it is considered that it cannot be validly said that the factual circumstances on which the approval was based continued.

\section{Fudicial Review of the Existence of an Actual Situation of Economic Emergency}

Now, leaving aside any matters relative to the control regarding timing and the adequacy relationship, I want to highlight certain criteria which the courts may adopt to check the existence of an actual situation of economic emergency.

One of the parameters considered to be correct in the judicial review of the situation of economic emergency is taking into account the Government's

Fallos (1993-316-3104); 27/12/1996, "Chocobar, Sixto C. c/ Caja Nac. de Prev. para el Personal del Estado y Servicios Públicos", Fallos (1996-319-3241).

116 CSJN, 26/8/1925, "Mango, Leonardo c/ Traba, Ernesto", Fallos (1925-144-219).

117 Constitutional Court of Spain, judgments 29/1982, 31/5/1982; 96/2014, 2/6/2014; 27/2015, 19/2/2015; 26/2016, 18/2/2016; 152/2017, 21/12/2017. See JuAN S. Ylarri, Los DECRETOS-LEYES Y EL CONTROL DE LA “EXTRAORDINARIA Y URGENTE NECESIDAD” 101-09 (2019). 
own acts. The judicial review of the actual economic emergency situation must not be limited to the verification of the formal declaration of emergency in a given regulation, but it must also consider other regulations - whether laws or decrees - issued by the Government itself, as those regulations may reveal governmental activities which are not consistent with the emergency situation officially declared. This would amount to normative inconsistency. Hence, this would permit to declare the unconstitutionality of such declaration, considering the lack of constitutional cause giving validity to the emergency regulation. This matter has already been discussed in Mango, already cited, in which, faced with housing shortage, leases were extended and owners were deprived from the use and enjoyment of their property. Among other matters, the Argentine Supreme Court has held that the fact that the situation of emergency did not exist anymore could "likely be inferred from the increase in taxes with which branches of government have levied urban properties lately, which would not be consistent with that situation of emergency". Another normative inconsistency is found in one of the extensions of the Emergency Act, Law No. 25561, and the early payment of the external debt, which was not due yet, with the International Monetary Fund, through decree No. 1599/05 for approximately 10 billion dollars. It was also a contradiction to extend the emergency law and at the same time issue decree No. 2010/09 creating the "Bicentennial Fund for Payment of Debts and Stability", underscoring that there was an unprecedented accumulation of reserves. ${ }^{118}$ This shows that with days of difference there were opposing views regarding the existence of a crisis. One can clearly see that there was inconsistency between the economic emergency declared and the reality. Therefore, it would be possible to hold that such declaration was unconstitutional due to the absence of the constitutional cause validating the emergency regulation.

The Argentine Supreme Court has considered other realities to determine the existence of emergency, such as legislative debates, the message accompanying a bill, or even the work at congressional committees. ${ }^{119}$ The Court also analyzed the content of the grounds of a decree, ${ }^{120}$ the information provided by the Executive in a legal action, ${ }^{121}$ or considered the consistency between the declaration of emergency by the Legislature and by the Executive. ${ }^{122}$ All these have been used by the Court in many cases. The Argentine Supreme

118 See Alberto B. Bianchi, Una reflexión sobre los decretos de necesidad y urgencia en las emergencias generales y de tracto sucesivo (El caso 'Redrado'), 236 El Derecho 845, 848 (2010).

119 Avico, Fallos (1934-172-21); Inchauspe, Fallos (1944-199-483); Videla Cuello, Fallos (1990313-1638).

120 Verrocchi, Fallos (1999-322-1726); Cooperativa del Trabajo Fast Limitada, Fallos (2003-3263180); CSJN, 7/12/2004, "Leguizamón Romero, Abel y otra c/ I.N.S.S.J. y P. s/ ordinario", Fallos (2004-327-5559); Consumidores Argentinos, Fallos (2010-333-633).

121 Avico, Fallos (1934-172-21); Inchauspe, Fallos (1944-199-483); Videla Cuello, Fallos (1990313-1638).

122 Avico, Fallos (1934-172-21); Guida, Fallos (2000-323-1566). 
Court has also considered external information, other than the statements made in the Congress or by the Executive, to decide on the existence of an emergency situation, such as specialized technical reports, ${ }^{123}$ and the recognition of the emergency situation by different sectors, such as the academia, ${ }^{124}$ among others.

In connection with the temporary validity of emergency regulations, the Argentine Supreme Court has held that emergency regulations must contain a defined term. But the Court has not held that emergency regulations should have a determinate term, but that at times it may happen that while emergency regulations must have a term, this term cannot be established beforehand, because of the features of the emergency. Since its early days, the Argentine Supreme Court has held that emergency regulations must be provisional restrictions, ${ }^{125}$ with temporary validity ${ }^{126}$ or transitory in nature. ${ }^{127}$ Anyway, it has admitted that the provisional nature of the emergency "cannot be fixed beforehand in a precise number of years or months. All that it is possible to reasonably state is that the emergency lasts the same as the causes that have given rise to it". ${ }^{128}$ While it may be said that this doctrine is still in force, in Tobar ${ }^{129}$ the Court invalidated a regulation which had admitted a salary reduction for a public employee, as it did not establish that the Government could terminate the emergency measure if the conditions giving rise to it changed.

\section{Reasonableness}

Finally, leaving aside the matter of the existence of an emergency situation, as well as the judicial review of the temporary duration of emergency regulations, it is essential that the courts analyze the reasonableness of the measures adopted. On this point, the Argentine Supreme Court has highlighted that while the emergency may authorize certain restrictions of some individual rights, admitting a temporary limitation of rights with monetary content, that would never justify the denaturation or elimination of the substance of those rights, as the governmental authority cannot validly run through the limit of the reasonableness of the measure. ${ }^{130}$

The control of reasonableness in the Argentine Constitution stems from the harmonious interaction between two constitutional regulations - Section 
14, allowing the Congress to regulate constitutional rights, and Section 28, imposing limits to this regulation, by establishing that any principles, rights, and guarantees recognized under the Constitution cannot be modified by the laws regulating their exercise. That permits to say that a law is reasonable when it has regulated a right without altering its substance. ${ }^{131}$ In connection with the power of the Argentine Congress, the doctrine of the Supreme Court has held that Section 28 of the Constitution has categorically provided that the law cannot modify the principles, guarantees, and rights under the Constitution with the pretext of regulating, as it not possible for the Constitution to destroy what it seeks to protect, and it cannot enshrine its denaturation. ${ }^{132}$

In connection with the development of this principle, authors have tried to delimitate its content. ${ }^{133}$ But, as I have already stated, the review of the reasonableness of economic emergency regulations has been too weak and excessively deferential to the decisions of the branches of government. Authors have tried to outline with more accuracy the scope of the reasonableness analysis of the regulations mostly restricting rights with economic content, especially in connection with the cost-benefit analysis ${ }^{134}$ or the proportionality principle. The proportionality principle has been widely discussed by foreign authors, ${ }^{135}$ and by Argentine authors. ${ }^{136}$ While its application is not exempt from criticism, ${ }^{137}$ the Argentine Supreme Court has held the possibility of applying this principle. It has maintained that to analyze the constitutional validity of a regulation "it is necessary to assess the reasonableness of regulations in terms of the relationship between the means chosen and the aims sought in connection with their adequacy, necessity, and/or proportionality". ${ }^{138}$ But the truth is that the Court has not accurately applied this doctrine. Therefore, it is desirable that the Argentine Supreme Court makes an appropriate reasonableness review of emergency regulations applying the proportionality principle in controlling

131 See Laura Monti, Emergencia y contratos administrativos, La LeY: Suplemento EsPecial EL Contrato Administrativo en la Actualidad, 64, 71 (2004).

132 CSJN, 9/4/1991, "Cortés, Alberto c/ Ministerio de Trabajo y Seguridad Social de la Nación s/ acción de amparo", Fallos (1991-314-225).

133 See Juan F. Linares, RaZonabilidad de las leyes. El 'DEbido Proceso' como garantía innominada en la Constitución Argentina (2002).

134 See, e.g., Estela Sacristán, Control judicial de las medidas de emergencia (a propósito del análisis costo-beneficio), El derecho Administrativo de la Emergencia, IV, 11 1-40 (Guillermo Scheibler, coord., 2005); Juan S. Ylarri, El control de razonabilidad de la emergencia económica: el análisis costo beneficio, LA LEY, AR/DOC/1501, 1-17 (2013).

135 See, e.g., Robert Alexy, Teoría de los derechos fundamentales (CEPC ed., 2007); Carlos Bernal Pulido, El principio de proporcionalidad (2006).

136 See, e.g., Juan Cianciardo, El principio de razonabilidad. Del debido proceso sustantivo al moderno Juicio de proporcionalidad (2004); Laura Clérico, El examen de proporCIONALIDAD EN EL DERECHO CONSTITUCIONAL (2009).

137 See, e.g., Jürgen Habermas, Facticidad y Validez 312 (Trotta ed., 1998).

138 CSJN, 28/6/2011, "Aceval Pollacchi, Julio César c/ Compañía de Radiocomunicaciones Móviles S. A. s/ despido”, Fallos (2011-334-799). 
economic emergency regulations ${ }^{139}$ and put an end to an interpretation which is highly deferential to economic emergency regulations, as it is even possible to say that the control of the reasonableness of these regulations has been relinquished in actual practice.

\section{Conclusion}

For almost a century, Argentina has been under permanent economic emergency. To face these emergency situations, different types of regulations have been issued. While in principle the declaration of the existence of an economic emergency is the province of the Congress, the truth is that throughout decades the Executive has been having an increasingly prevailing role by issuing delegated decrees, with a delegation by the Congress, or by issuing decrees of necessity and urgency. The Argentine Supreme Court has established certain requirements for economic emergency regulations to be valid. However, as it has been explained, the branches of government have abused these regulations. At the same time, courts have been extremely deferential to the decision of the Congress or the president. This is why a change of the judicial review of economic emergency regulations is imperative. It is also necessary to apply a restrictive interpretation of such regulations, with the purpose of adequately protecting economic liberties and, therefore, making it possible that the Constitution is observed.

139 See Juan S. Ylarri, El principio de proporcionalidad en la emergencia económica, MicroJuris, April 4,2015 , at 1-21. 